\title{
Development and Testing of a Power Operated Coconut Oil Expeller
}

\author{
Amretha Krishnan. A. K*, Manshooba. P. M, Sa-ada Abdurahiman, \\ Saroop. C. L, Dr. Jayan. P. R** \\ *Department of Farm Power Machinery and Energy, K.C.A.E.T, Tavanur, Malappuram, Kerala-679573 \\ ** Professor and Head (FPME) Department of Farm Power Machinery and Energy, K.C.A.E.T, Tavanur, \\ Malappuram, Kerala-679573
}

\begin{abstract}
Although, large scale coconut oil extraction is excessively available, it cannot meet the requirements for a small scale farmer. Deficiency in coconut production and high cost of coconut oil extraction impede the small scale coconut farming. To overcome these problems a power operated coconut oil expeller was developed and tested. It consists of a screw shaft, a prime mover, barrel, hopper and outlets are fitted on a supporting frame. The feed rate was optimized to $3.5 \mathrm{~kg} \mathrm{~h}^{-1}$ and in order to increase oil recovery. The sliced copra is fed to expeller through hopper and get compressed between screw shaft and the barrel. The effective compression and the amount oil recovered depend on moisture content. The optimum moisture was founded as $7.2 \%(\mathrm{wb})$, and observed that at this moisture content $53.25 \%$ maximum of oil recovery was obtained. The efficiency of the expeller is 84.8 at a working cost @ Rs 4 per kg.
\end{abstract}

Keywords: Coconut oil, Copra, Expeller, Screw shaft

\section{INTRODUCTION}

Coconut (Cocosnucifera) is one of the most important agricultural crops in lowlands. The coconut is known for its great versatility, all parts of coconut are useful in one way or other. Commonly used edible by-products of coconut are coconut milk and coconut oil. Normally coconut oil obtained from dried coconut. It can be also obtained without drying coconut and it is known as virgin coconut oil. Dried coconut meat (copra) is used after for producing coconut oil. Two types of copra namely milling and edible are made in India. Milling copra is used to extract oil while edible grade of copra is consumed as dry fruit. Milling copra is generally made by sun drying or artificial means. Substantial quantity of milling copra is made using modern hot air driers resulting in availability of superior quality copra which in turn is used for producing the best grade coconut oil.

For the preparation of copra, the de husked coconuts are dried until it attains 6-8\% m.c (db). The dried copra is ground, flaked and cooled until moisture is brought down to $3 \%$ moisture content. After the oil extraction the cake contain $7 \%$ of oil. On an average

1000 nuts yield $180 \mathrm{~kg}$ of copra, which yield $120 \mathrm{~kg}$ of oil and $60 \mathrm{~kg}$ of meal. The coconut cake is the residue obtained after the extraction of oil from copra which is mainly used as a cattle feed. Coconut cake contain 4-5\% of oil which is extracted by solvent extraction process. The oil is generally used for industrial purpose and de-oiled cake is used to make mixed cattle feed. There are several units in the country especially in Kerala. In the case of traditional methods the coconut oil was extracted using chaks driven by using animal power. This process was time consuming and not efficient. Nowadays, coconut oil extracting industries are having improved modern machines like twin screw press to extract the oil with less power consumption and increased oil quality (Isobe et al., 1997).

Compared to other oil seeds, copra is harder and is very difficult to extract oil from it. This fact retards the growth of small industries and they cannot afford high costly machines. There are no simple methods using for extraction of coconut oil for the house hold purposes. Large mechanical expellers for coconut oil extraction are available, but they are not suitable for domestic purpose. This made the necessity to introduce a simple oil expeller operated by an electric motor for domestic use. Hence, a study was conducted to develop and test a power operated coconut oil expeller suitable for domestic purpose with less operating cost.

\section{MATERIALS AND METHODS}

The power operated coconut oil expeller mainly consist of a screw shaft, barrel, hopper, oil and cake output. A $3 \varnothing$ induction motor having $2 \mathrm{hp}$ with $1440 \mathrm{rpm}, 230 \mathrm{v}$ and $50 \mathrm{hz}$ was used as a prime mover. Spider coupling made of cast iron is used for the transmission of rotary motion from prime mover to the expeller shaft. Screw shaft (Fig. 1) is the actual working component of the expeller. The 

ISSN : 2248-9622, Vol. 7, Issue 7, ( Part -4) July 2017, pp.01-05

screw shaft is made of MS rod having diameter of $47 \mathrm{~mm}$ and length of $300 \mathrm{~mm}$ with thread having several $25 \mathrm{~mm}$ pitch. This screw shaft was machined in such a way that, it has 8 turns with a decreasing depth from $12 \mathrm{~mm}$ to $9 \mathrm{~mm}$ on its length to provide tapering and to ensure progressive compression. On rotation of the screw shaft, the sliced copra get compressed in the enclosed barrel and oil is squeezed.

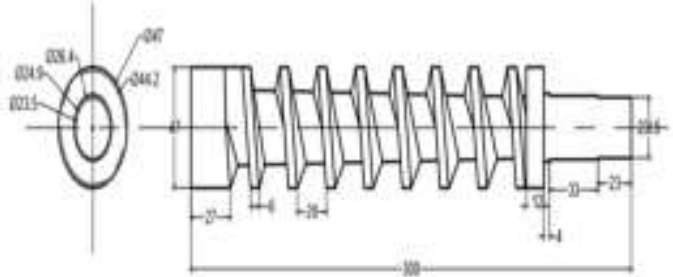

(All dimensions are in $\mathrm{mm}$ )

Fig. 1: Prototype of Screw shaft

A barrel was made of GI pipe having diameter $54 \mathrm{~mm}$. It was machined to a length of 210 $\mathrm{mm}$. A slot of $55 \times 50 \mathrm{~mm}$ was made on its upper side for an opening to the hopper. Another slot of $105 \times 1.5 \mathrm{~mm}$ was provided at the bottom of the barrel for oil outlet and at the other extreme end of the barrel with a cap to obtain the cake output. The hopper was made of $15 \mathrm{~mm}$ thick MS plate. The size of the hopper was $130 \times 125 \mathrm{~mm}$ at the top and $55 \times 50$ $\mathrm{mm}$ at the bottom with small aperture. Aperture dimension can be adjusted according to the feed rate.

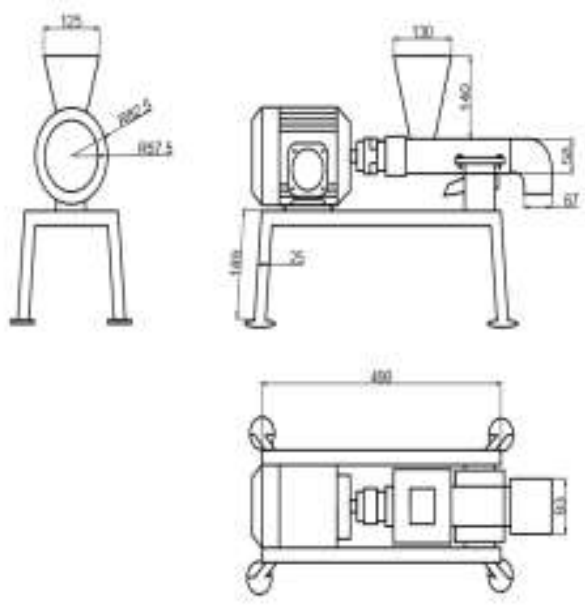

Fig. 2: Power operated coconut oil expeller (All dimensions are in $\mathrm{mm}$ )

\subsection{Working}

When the prime mover is started, its rotary motion is transferred to the screw shaft. The sliced copra feed through the hopper get compressed between barrel and screw shaft. This compression will squeeze out oil from copra through the oil output and the cake is expelled out through the cake output. This cake is again passed through the expeller in order to obtain maximum oil recovery. The moisture content of copra, feed rate, size and shape of the sliced copra affect the output of the machine.

\subsection{Moisture Content}

It is the amount of moisture content present in the given dried coconut meat sample, expressed in percentage. The sample is placed in an oven under controlled temperature conditions of $80^{\circ} \mathrm{C}$ for a period of $12 \mathrm{~h}$

$$
\operatorname{m.c}(\%)=\left(\frac{\mathrm{M}_{\mathrm{i}}-\mathrm{M}_{\mathrm{f}}}{\mathrm{M}_{\mathrm{i}}}\right) \times 100
$$

Where

m.c : Moisture content, \% (wb)

$\mathrm{M}_{\mathrm{i}}$ : Initial weight of copra, $\mathrm{g}$

$\mathrm{M}_{\mathrm{f}}$ : Final weight of copra, $\mathrm{g}$

\subsection{Feed rate}

The variation in feed rate may leads to different level of compression and ultimately it affects the oil yield. Therefore an optimum feed rate is required for the smooth operation of oil expeller.

Feed rate $\left(\mathrm{kg} \mathrm{h}^{-1}\right)=\frac{\mathrm{Quantity} \mathrm{of} \mathrm{copra} \mathrm{fed}(\mathrm{kg})}{\text { Time taken }(\mathrm{h})}$

\subsection{Calibration}

The oil expeller was calibrated to as follows: Seven samples of copra each of $500 \mathrm{~g}$ were taken and the durations to feed these samples were varied.

Table. 1: Calibration of the oil expeller

\begin{tabular}{|c|c|c|c|}
\hline Sample & $\begin{array}{c}\text { Weight } \\
\text { of copra } \\
(\mathrm{kg})\end{array}$ & $\begin{array}{c}\text { Time taken } \\
\text { for feeding } \\
(\mathrm{h})\end{array}$ & $\begin{array}{c}\text { Feeding } \\
\text { rate } \\
\left(\mathrm{kg} \mathrm{h}^{-1}\right)\end{array}$ \\
\hline 1 & 0.5 & 0.081 & 6.17 \\
\hline 2 & 0.5 & 0.095 & 5.26 \\
\hline 3 & 0.5 & 0.110 & 4.55 \\
\hline 4 & 0.5 & 0.130 & 3.85 \\
\hline 5 & 0.5 & 0.137 & 3.65 \\
\hline 6 & 0.5 & 0.150 & 3.33 \\
\hline 7 & 0.5 & 0.256 & 1.95 \\
\hline
\end{tabular}

Corresponding to feed rate the working condition of the expeller was analyzed. For a feed rate of $1.95 \mathrm{~kg} \mathrm{~h}^{-1}$, the machine was operated without any hindrance. But, it resulted in partially compressed copra with decreased oil yield. For 3.3 
Amretha Krishnan. A. K.et.al. Int. Journal of Engineering Research and Application www.ijera.com ISSN : 2248-9622, Vol. 7, Issue 7, ( Part -4) July 2017, pp.01-05

$\mathrm{kg} \mathrm{h}^{-1}$ and $3.65 \mathrm{~kg} \mathrm{~h}^{-1}$ feed rates, the machine was worked smoothly and oil recovery was increased compared to previous feed rate. For the feed rates of $3.85,4.55,5.26$, and $6.17 \mathrm{~kg} \mathrm{~h}^{-1}$ resulted an overheating of the expeller causing, burning of oil and disruption during the working of expeller.

The optimum feed rate for the proper working and for maximum oil recovery was found out as 3.33 to $3.65 \mathrm{~kg} \mathrm{~h}^{-1}$. So for the further operation of oil expeller, an average feed rate of 3.5 $\mathrm{kg} \mathrm{h}^{-1}$ was adopted. To vary the time for feeding, a slider was provided just above the aperture of the hopper to ensure optimum feed rates.

\section{RESULT AND DISCUSSION}

Tests were conducted to find out the optimum moisture content, feed rate and efficiency of expeller. The test results are given below.

\subsection{Size and shape of copra}

Size and shape of copra sample is an important variable which affects the amount of oil obtained and easiness of the operation. Larger sized samples get blocked in the clearance between the screw shaft and barrel, whereas small sized samples get discharged without proper compression.

\subsection{Oil output}

Oil output is an important factor which affects the overall efficiency of the oil expeller.

$$
\text { Oil output }(\%)=\left(\frac{\text { W eight of oil }}{\text { W eight of copra }}\right) \times 100
$$

\subsection{Cake output}

Cake is squeezed out during the oil expulsion. Cake output should be minimum, in order to obtain maximum oil recovery.

Cake output $(\%)=\left(\frac{\text { W eight of cake }}{\text { Weight of copra }}\right) \times 100$

For the determination of oil recovery with respect to moisture content, a test was conducted. During the test seven $2 \mathrm{~kg}$ samples, each having different moisture content was used. During the first pass, $2 \mathrm{~kg}$ samples was fed to the expeller. During the second pass, cake obtained from the first pass was fed to the expeller. During the third pass, cake obtained from the second pass was fed to the expeller. Total oil recovery from one sample will be the sum of the oil recovery from all the three passes. Each sample was fed separately to the expeller. The test result are shown in the table given below along with the percentage loss of each sample.

Table. 3: Determination of oil recovery with respect to moisture content

\begin{tabular}{|c|c|c|c|c|c|}
\hline \multirow{2}{*}{$\begin{array}{c}\text { Moisture content } \\
\text { of copra }(\% \mathrm{wb})\end{array}$} & \multirow{2}{*}{ Batch } & \multicolumn{3}{|c|}{ Weight $(\mathrm{kg})$} & \multirow{2}{*}{$\begin{array}{c}\text { Coss } \\
(\%)\end{array}$} \\
\cline { 3 - 5 } & & Sample used & Oil & Cake & 6.60 \\
\hline 5.6 & I & 2.000 & 0.654 & 1.214 & 1.89 \\
\hline & II & 1.214 & - & 1.191 & 0.92 \\
\hline & III & 1.191 & & 1.180 & 3.35 \\
\hline & I & 2.000 & 0.680 & 1.253 & 8.22 \\
\hline & II & 1.253 & - & 1.150 & 7.82 \\
\hline & III & 1.150 & - & 1.060 & 5.10 \\
\hline & I & 2.000 & 0.613 & 1.285 & 7.86 \\
\hline & II & 1.285 & 0.296 & 0.888 & 7.54 \\
\hline & III & 0.888 & & 0.821 & 4.20 \\
\hline & I & 2.000 & 0.582 & 1.334 & 7.49 \\
\hline & II & 1.334 & 0.308 & 0.926 & 6.90 \\
\hline & III & 0.926 & 0.175 & 0.687 & 5.20 \\
\hline & I & 2.000 & 0.464 & 1.432 & 6.77 \\
\hline & II & 1.432 & 0.279 & 1.056 & 4.26 \\
\hline & III & 1.056 & 0.123 & 0.888 & 4.30 \\
\hline & I & 2.000 & 0.412 & 1.502 & 2.39 \\
\hline & ii & 1.502 & 0.191 & 1.275 & 8.86 \\
\hline & III & 1.275 & 0.056 & 1.106 & 4.65 \\
\hline & I & 2.000 & 0.406 & 1.501 & 8.19 \\
\hline & II & 1.501 & 0.103 & 1.275 & \\
\hline & III & 1.275 & 0.027 & 1.156 & 7.21 \\
\hline
\end{tabular}


During the test, copra samples with moisture content $5.6 \%, 6.5 \%$ and 6.8 didn't yield oil recovery from all the three passes. Remaining samples yield oil during the 3 passes. For sample with moisture content $7.2 \%$ yielded $1.065 \mathrm{~kg}$ of oil from $2 \mathrm{~kg}$ of copra. Which was the highest oil recovery obtained during the test. Considering the working conditions and optimized feed rate, $7.2 \%$ m.c was the most appropriate moisture content for maximum oil recovery.

\subsection{Efficiency}

Complete extraction of oil from copra is not possible by mechanical methods. Solvent extraction methods are most efficient way to determine maximum oil content present in a (Lou et al., 2009). Hence, solvent extraction is needed to determine the maximum oil content present in the copra. Soxhlet apparatus was used to determine the oil content, in which hexane was used as the solvent. Oil obtainduring the chemical extraction method was $62.8 \%$ in weight basis, which is considered as the maximum oil recovery from copra and efficiency of oil expeller is calculated based on this data.

Efficiency $(\%)=\left(\frac{\text { oil output }}{62.8}\right) \times 100$

The efficiency of the power operated coconut oil expeller was found out by estimated oil recovery from copra. The bar diagram shown below represents the efficiency of oil expeller corresponding to each moisture content. A maximum oil recovery of $84.8 \%$ was obtained for the sample of $7.2 \%$ (wb) moisture content.

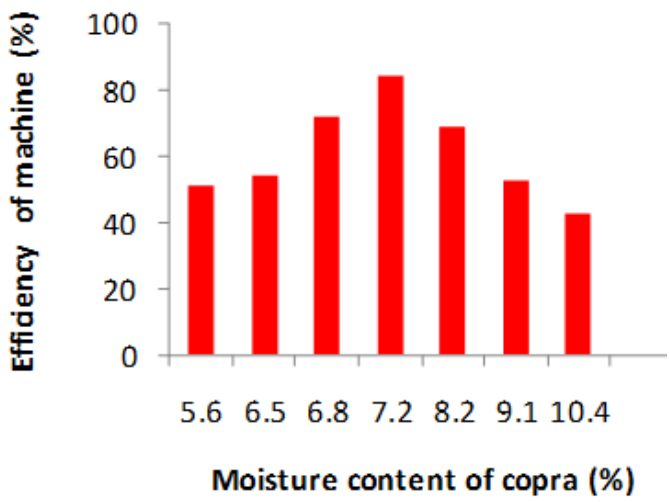

Fig. 4: Efficiency of coconut oil expeller with respect to different moisture content

\subsection{Cost analysis}

The capacity of the power operated coconut oil expeller was $3.5 \mathrm{~kg} \mathrm{~h}^{-1}$. The unit used a $1.5 \mathrm{~kW}$ electric motor with a maximum power consumption of $1.5 \mathrm{~kW} \mathrm{~h}^{-1}$. Operation cost with the expeller is Rs 10.59 per hour and this was calculated by considering fixed and variable costs of the oil expeller. The cost required to expel oil from $1 \mathrm{~kg}$ of copra is Rs 4. The Cost incurred for the marginal level oil mills is Rs 12 per $\mathrm{kg}$ of copra. Hence a cost reduction of $66.66 \%$ obtained when operated with this domestic unit.

\section{CONCLUSION}

From the test result it is concluded that the power operated coconut oil expeller is suitable for domestic scale coconut oil extraction. Maximum oil recovery of $84.8 \%$ was obtained with $7.2 \%$ moisture content. Working cost of the expeller was Rs 4 per $\mathrm{kg}$, which compared to marginal level oil extraction gives a cost reduction of $66.66 \%$. From the whole experiment and analysis we found some modification suggestions for the better performance of oil expeller. They are,

- Provide a water jacket to avoid over heating

- Provide a mesh at the oil outlet to avoid the presence of sediments in the oil

- Introduce a speed reduction unit to handle at various fee

\section{ACKNOWLEDGEMENT}

We acknowledge all the support rendered by the department of Farm Power Machinery and Energy of KCAET, Kerala Agricultural University for conducting the research work.

\section{REFERENCES}

[1] Ali, N.S., Mahmod, W.M.W., Jaharah, A.G., CheHaron, C.H., and Rizal, M. 2014. Design and Analysis of Single Screw Extruder for Jatropha Seeds Using Finite Element Method. Research Journal of Applied Science, engineering and Technology. 7: 2098-2105.

[2] Álvarez-Ortí, M., Quintanilla, C., Sena, E., Alvarruiz, A., Pardo, J.E., Grasa, I.D., Seville., Spain. and Grasasy, A. (2012). The effects of a pressure extraction system on quality parameters of different virgin pistachio. Pistaciavera Larnaka., 63(3): 260-266.

[3] Bargale, P.C., Ford, R.J., Sosulski, F.W., Wulfsohn, D. and Irudayaraj, J. (1999). Mechanical oil expression from extruded Soybean samples. JAOCS., 76(2): 223229. 
[4] Bhattacharjee, P., Singal, R. S. and Twari, S. R. (2007). Super critical carbon dioxide extraction of cotton seed oil. Journal of food engineering., 79: 892-898.

[5] Evon, P.H., Vandenbossche, V., Pontalier, P.Y., and Rigal, L. 2007. Direct extraction of oil from sunflower seeds by twin-screw extruder according to an aqueous extraction process: Feasibility study and influence of operating conditions. Industrial Crops and Products. 26: 351359.

[6] Ghosh, P. K., Paramita, B. SouvikMitraandMousumi.2O14

Physicochemical and Phytochemical Analyses of Copra and Oil of Cocosnucifera L. (West Coast Tall Variety). International Journal of Food Sciences. 45: 234-242.

[7] Isobe, S., Zuber, F., Manebog, E.S., Lite, L., Uemura, K. and Noguchi, A. (1997). Solid-liquid Separation of agricultural products using twin screw press and electro osmosis. Japan Agricultural Research Quarterly., 31(2): 137-146.

[8] Kamu, J.M. and Some, D.K. (2008). Performance of the ram press with different oil seeds. Journal Article., 39(1): 61-64.
[9] Kartika, I.A., Pontalier, P.Y., Rigal, L. 2010. Twin screw extruder for oil processing of sunflower seeds:Thermomechanical pressing and solvent extraction in single step. Industrial crops and products. 32: 297-304.

[10] Lou, Z., Wang, H., Zhang, M. and Wang, Z. (2009). Improved extraction of oil from chickpea under ultra sound in a dynamic system. Journal of food engineering., 98: 13-18.

[11] Milsum, J. N., and Georgi, C. D. V. 1938. Small scale extraction of palm oil. Malayan Agricultural Journal. 26: 53-8.

[12] Moigradean, D., Mariana, A and Gogoasa, L. 2012. Quality characteristics and oxidative stability of coconut oil during storage. Journal of Agroalimentary Processes and Technologies. 18: 272-276.

[13] Musonge, P. and Baryeh, E.A. (1991). Variety, age and soil type affect solid content of palm oil. Agricultural international., 43(10): 294-296.

[14] Roberto, C., Guarte, Werner,M. and Kellert, M. 1996. Drying characteristics of copra and quality of copra and coconut.Postharvest Biology and Technology. 9: 361-372.

International Journal of Engineering Research and Applications (IJERA) is UGC approved Journal with Sl. No. 4525, Journal no. 47088.

Amretha Krishnan. A. K. "Development and Testing of a Power Operated Coconut Oil Expeller." International Journal of Engineering Research and Applications (IJERA) 7.7 (2017): 01-05. 